\title{
Comparison of trimethoprim-sulphamethoxazole and penicillin in the treatment of gonorrhoea
}

\author{
J. D. H. MAHONY, J. S. MCCANN*, AND J. R. W. HARRIS† \\ From the Department of Venereology, Royal Victoria Hospital, Belfast
}

Sulphonamides inhibit the biosynthesis of bacterial DNA by blocking its metabolic pathway at the point where para-aminobenzoic acid is converted to dihydrofolic acid. Trimethoprim attacks the metabolic pathway at the next step by inhibiting the enzyme dihydrofolic acid reductase; fortunately, however, it appears to have very little activity against the corresponding enzyme of mammalian tissues (Hitchings and Burchall, 1965). The mode of action of these two drugs provides an easily understood reason why their combined effect should be synergistic and bactericidal, and also why this combination provides a means of treating successfully some infections due to sulphonamide-resistant organisms (Elion, Singer, and Hitchings, 1960).

That trimethoprim-sulphamethoxazole is effective in the treatment of gonorrhoea has been well established by many workers including Csonka and Knight (1967) and Carroll and Nicol (1970). It was felt, however, that there was a place for a study which would compare the results of trimethoprim-sulphamethoxazole with those of penicillin. In this study treatment with one or other of these therapies was determined by a randomized system of selection and bacterial sensitivity tests were employed in every case.

\section{Material and methods}

This study was carried out on 276 patients (188 males and 88 females) with gonorrhoea who attended the Department of Venereology at the Royal Victoria Hospital, Belfast, from November 5, 1969, until May 14, 1971. The 21 males who failed to respond (sixteen to penicillin and five to the trimethoprim-sulphamethoxazole regime) were subsequently successfully treated with the alternative regime. There were also ten patients out of the original 188 who were considered on historical evidence to have acquired a total of twelve re-infections. There was therefore a total of 221 'treatments' in the 188 males under consideration.

Received for publication February 6, 1973

$\star$ Present address: Kent and Canterbury Hospital, Canterbury, Kent

†Present address: Royal Infirmary, Sheffield
Only four of the 88 females required re-treatment and as one of them defaulted at the beginning of the re-treatment, a total of 91 'treatments' remained for assessment.

Diagnosis was made by direct microscopy of urethral smears from the males and of urethral, cervical, vaginal, and sometimes rectal smears from the females. Gramstained smears were examined in the clinic laboratory in the first place, and a duplicate set of smears, together with cultures, was examined in the main hospital laboratory.

The patients were seen at frequent intervals during the first 2 to 3 weeks after starting treatment, and then at longer intervals for up to 6 months. Smears and cultures were taken at each examination as at the first visit.

Sensitivity tests were carried out routinely in all cases. Culture plates containing two discs, one of $1.25 \mu \mathrm{g}$. trimethoprim and $23.75 \mu \mathrm{g}$. sulphamethoxazole, and the other of 1 unit penicillin $G$, were inoculated from a primary colony grown on Thayer-Martin medium, and incubated for $24 \mathrm{hrs}$ in an atmosphere of 5 to 10 per cent. $\mathrm{CO}_{2}$.

\section{TREATMENT SCHEDULES}

The primary dosage regimes adopted were: Males

(a) A single intramuscular injection of 900,000 units procaine penicillin.

(b) Tablets of trimethoprim-sulphamethoxazole (each containing $400 \mathrm{mg}$. suphamethoxazole and $80 \mathrm{mg}$. trimethoprim). The patient took four tablets in the consulting room at his first visit and then two tablets at bed-time and on rising in the morning until a total of 24 tablets had been taken.

Females

(a) 1.2 mega units 'Penidural All Purpose' (benzathine penicillin 600,000 i.u., procaine benzylpenicillin 300,000 i.u., and benzyl penicillin 300,000 i.u.) on diagnosis, followed by 900,000 i.u. procaine penicillin on the following day.

(b) Trimethoprim-sulphamethoxazole as for males.

\section{Assessment of response and results}

\section{MALES}

It was considered that the 'initial' response would give the best single indication of the effect of the therapy as it 
is never possible to be sure after a period of a week or more whether a recurrence has been due to relapse or re-exposure. Initial response was classified as successful if smears and cultures were negative for Neisseria gonorrhoeae, and remained so from the 2 nd to the 7 th day of surveillance. On this basis the failure rate was 4.2 per cent. with trimethoprim-sulphamethoxazole and $15 \cdot 5$ per cent. with penicillin (Table I).

\section{TABLE I Initial response in male patients (2 to 7} days)

\begin{tabular}{|c|c|c|}
\hline \multirow[b]{2}{*}{ No. of cases } & \multicolumn{2}{|l|}{ Treatment } \\
\hline & $\begin{array}{l}\text { Trimethoprim- } \\
\text { sulphamethoxazole }\end{array}$ & Penicillin \\
\hline $\begin{array}{l}\text { Primary treatment } \\
\text { Re-infections }\end{array}$ & $\begin{array}{r}94 \\
8\end{array}$ & $\begin{array}{r}94 \\
4\end{array}$ \\
\hline regime & 16 & 5 \\
\hline Total treated & 118 & 103 \\
\hline Total failures & 5 ( 4.2 per cent.) & 16 ( 15.5 per cent. $)$ \\
\hline
\end{tabular}

It is not suggested that initial response can be equated with cure, but it provides a reasonable standard by which the response to both methods of treatment can be compared. Every patient in the trial was seen at least once between the 2nd and the 7th day. Any case which showed positive smears or cultures on any day between the 2nd and 7 th (inclusive) was classified as a treatment failure. It is realized that this regime meant that the penicillintreated patients had received their total treatment before the first review, whereas many of those given trimethoprim-sulphamethoxazole had received only part of their total dosage at this stage. In spite of this, the initial response rate was better in the trimethoprim-sulphamethoxazole group than in the penicillin group.

There were no defaulters among the males in the first 14 days of treatment, and the majority attended for at least 4 weeks. We did not observe any failures in males that did not occur within the first 7 days of starting treatment. In this respect our findings differ from those of Wright and Grimble (1970) who found, on the basis of Gram-stained smears, that treatment with trimethoprimsulphamethoxazole gave a relapse of 38 per cent. within 2 weeks of starting treatment; they also found that this treatment tended to produce a carrier state, but this too we were unable to confirm. All the patients who failed to respond to the first treatment subsequently responded to the alternative regime.

\section{FEMALES}

Recognizing the difficulties associated with the bacteriological diagnosis of gonorrhoea in females, it was decided to extend the period of initial response to the 28th day from the 1st day of treatment. The results were considered in two separate groups: those who were kept under surveillance for over 28 days and those who attended for 7 to 27 days. In practice, this distinction lost its significance in view of the low overall failure rate in female patients (Tables II and III).

TABLE II Response in females kept under surveillance between 7 and 27 days

\begin{tabular}{llll}
\hline Treatment & $\begin{array}{l}\text { Trimethoprim- } \\
\text { sulphamethoxazole }\end{array}$ & Penicillin \\
$\begin{array}{l}\text { Total cases } \\
\begin{array}{l}\text { Recurrences (relapse } \\
\text { or re-infection) }\end{array}\end{array}$ & $\begin{array}{c}14 \\
9\end{array}$ & 1 \\
\hline
\end{tabular}

TABLE III Response in females kept under surveillance for 28 days or more

\begin{tabular}{llll}
\hline & $\begin{array}{l}\text { Trimethoprim- } \\
\text { sulphamethoxazole }\end{array}$ & Penicillin \\
\cline { 3 - 4 } $\begin{array}{l}\text { Tretal cases } \\
\text { Recurrences (Relapse }\end{array}$ & 34 & 34 \\
or re-infection) & 1 & 2 \\
\hline
\end{tabular}

SIDE-EFFECTS

Neither drug gave rise to any significant toxic effects in either men or women.

\section{Discussion}

The results show that 900,000 i.u. procaine penicillin as a routine treatment of gonorrhoea for males in Northern Ireland gives an unacceptably high failure rate of 15.5 per cent. This compares very unfavourably with the failure rate of only 4.2 per cent. in males treated with trimethoprim-sulphamethoxazolea result which is similar to that obtained by Carroll and Nicol (1970) using a similar dosage (4 tablets daily for 5 days).

The world-wide decrease in the effectiveness of penicillin as a treatment for gonorrhoea has been well documented by Catterall (1970). Although 900,000 i.u. penicillin would be regarded by most workers in Great Britain as a somewhat low dosage, it is three times greater than that which was found effective in Belfast in 1966. Arya, Pearson, Rao, and Blowers (1970) stated that, whereas 0.3 m.u. penicillin aluminium monostearate (PAM) was regarded as adequate treatment for gonorrhoea in Uganda in 1961, a dosage of 1.2 m.u. was yielding a failure rate of 17.9 by 1966 and of 32 per cent. by 1968 . In 1969 they were giving $2.4 \mathrm{~m}$.u. and were expecting that this, too, might eventually prove inadequate. Olsen and Lomholt (1969) gave $1 \mathrm{~g}$. probenecid followed 15 to 30 minutes later by 5 m.u. benzyl penicillin as routine treatment for gonorrhoea. This resulted in a cure rate of 99 per cent. and, moreover, reduced the prevalence of penicillin-resistant strains of the gonococcus in Greenland from 56 per cent. to 19 per cent. 
The motivation for using as low a dose of penicillin as will give an acceptable cure rate for gonorrhoea derives partly from the fear of 'masking' syphilis. Woodcock (1971) has given detailed consideration to this concept and, although he avoids dogmatism, on the balance of probabilities he appears to consider that 'penicillin given for gonorrhoea is more likely to cure incubating syphilis than to mask it'. Against this, Hallinger (1968) found that seven out of eight patients with primary syphilis relapsed within 3 months of receiving the routine treatment for gonorrhoea in Greenland, i.e. $1 \mathrm{~g}$. probenecid followed by 5 m.u. benzyl penicillin. If a dose as large as this fails to cure primary syphilis, one may have reason to doubt whether a smaller dose would always cure incubating syphilis. On balance, we are inclined to the view that the non-treponemicidal properties of trimethoprim-sulphamethoxazole are an advantage, in that a 3-month follow-up period of patients with gonorrhoea is sufficient to exclude concomitantly acquired syphilis. It is our policy to keep penicillin-treated patients under surveillance for 6 months if possible.

Neither penicillin (Gartman and Leibovitz, 1955; Morton and Morrison, 1963) nor trimethoprimsulphamethoxazole (Carroll and Nicol, 1970) can be regarded as effective agents in the treatment of nongonococcal urethritis. Nevertheless, in the present series, the incidence of NGU (developing from the 8th to the 28th day after treatment was started) in the trimethoprim-sulphamethoxazole group (7 out of $118 ; 5.9$ per cent.) was found to be significantly lower than that in the penicillin group (20 out of $103 ; 19.4$ per cent.). While by no means advocating trimethoprim-sulphamethoxazole as a treatment for NGU, we suggest that it may have some value in aborting NGU in males who have acquired it concomitantly with gonorrhoea.

Tables IV and V show that resistance in vitro and clinical response bore little relationship.

TABLE IV Patients showing resistance to trimethoprim-sulphamethoxazole in vitro

\begin{tabular}{|c|c|c|c|}
\hline Treatment & Penicillin & $\begin{array}{l}\text { Trimethoprim- } \\
\text { sulphamethoxazole }\end{array}$ & Total \\
\hline $\begin{array}{l}\text { No. showing } \\
\text { resistance } \\
\text { in vitro } \\
\text { No. of failures }\end{array}$ & $\begin{array}{l}9 \\
2\end{array}$ & $\begin{array}{r}11 \\
0\end{array}$ & $\begin{array}{r}20 \\
2\end{array}$ \\
\hline
\end{tabular}

None of the trimethoprim-sulphamethoxazole resistant group failed to respond to trimethoprimsulphamethoxazole therapy (Table IV).

When the series is considered as a whole (Tables I, II, III, IV, V), it can be seen that nineteen patients showed clinical resistance to penicillin, but only seven gonococcal strains showed resistance in vitro to discs containing 1 i.u. penicillin.

TABLE V Patients showing resistance to penicillin in vitro

\begin{tabular}{|c|c|c|c|}
\hline Treatment & Penicillin & $\begin{array}{l}\text { Trimethoprim- } \\
\text { sulphamethoxazole }\end{array}$ & Total \\
\hline $\begin{array}{l}\text { No. showing } \\
\text { resistance } \\
\text { in vitro } \\
\text { No. of failures }\end{array}$ & $\begin{array}{l}2 \\
1\end{array}$ & $\begin{array}{l}5 \\
0\end{array}$ & $\begin{array}{l}7 \\
1\end{array}$ \\
\hline
\end{tabular}

Note There was no failure on trimethoprim-sulphamethoxazole. The three failures on penicillin in Tables IV and $\mathrm{V}$ all responded to trimethoprim-sulphamethoxazole.

Conversely, there were only six patients who showed clinical resistance to trimethoprim-sulphamethoxazole therapy compared with twenty who had strains of gonococci which showed resistance in vitro.

A more refined method of testing for sensitivity to penicillin might have shown a better correlation with the results of treatment.

\section{Summary}

A trial was carried out in Belfast to compare the efficacy of trimethoprim-sulphamethoxazole and penicillin in the treatment of gonorrhoea.

The treatment of 103 men with the routine dosage of 900,000 i.u. penicillin used at the clinic gave a failure rate of 15.5 per cent. against a failure rate of only 4.2 per cent. in 118 men given trimethoprimsulphamethoxazole ( 4 tablets initially followed by 2 twice daily for 5 days).

The results of the latter treatment in women were excellent ( 2 per cent. recurrence rate). A higher dosage of penicillin was used in females (1.2 m.u. fortified benzathine penicillin followed by 900,000 i.u. procaine penicillin on the following day) and the recurrence rate was 7 per cent.

No significant toxic reactions were noted from either form of treatment.

The possible advantages of using a non-treponemicidal agent are briefly considered.

Our thanks are due to Dr. H. Holgate, of Roche Products Limited, for his valuable help in providing a randomized system of patient selection, and to Roche Products Limited for the supply of Bactrim and sensitivity discs used in the investigation.

Our thanks are also due to Dr. W. T. Ferguson, of the Department of Bacteriology, Royal Victoria Hospital, 
Belfast, and to Mr. H. Cox and Mr. J. Rodgers of the same department, who were responsible for carrying out and interpreting most of the sensitivity tests.

We are grateful also to Mr. H. J. Dougan, Senior Venereology Technician in the department, Sister R. M. Shannon, and other members of the staff for valuable contributions in recording and searching the records.

\section{References}

Ayra, O. P., Pearson, C. H., Rao, S. K., and Blowers, R. (1970) Brit. F. vener. Dis., 46, 214

CARRoll, B. R. T., and Nicol, C. S. (1970) Ibid., 46, 31

Catterall, R. D. (1970) Brit. f. Hosp. Med., 3, 55

CsonkA, G. W., and KNIGHT, G. J. (1967) Brit. f. vener. Dis., 43, 161

Elion, G. B., SingeR, S., and Hitchings, G. H. (1960) Antibiot. and Chemother., 10, 556

Gartman, E., and LeIbovitz, A. (1955) Brit. f. vener. Dis., 31, 92

HALlINGER, L. (1968) Acta derm.-venereol. (Stockh.), 48, 260

Hitchings, G. H., and BuRchall, J. J. (1965) Advanc. Enzymol., 27, 417

Morton, R. S., and Morrison, A. I. (1963) Brit. f. vener. Dis., 39, 244

Olsen, G. A., and Lomholt, G. (1969) Ibid., 45, 144
WoODCoCK, K. R. (1971) Ibid., 47, 95

WRIGHT, D. J. M., and GRIMBLE, A. S. (1970) Ibid., 46, 34

Comparaison entre la triméthoprime-sulfaméthoxazol et la pénicilline dans le traitement de la gonococcie

\section{SOMMAIRE}

Une étude fut menée à Belfast pour comparer l'efficacité de la triméthoprime-sulfaméthoxazol et la pénicilline dans le traitement de la gonococcie.

Alors que le traitement de 103 hommes par la dose habituelle de 900.000 u. de pénicilline en usage à la clinique donna un taux d'échec de 15,5 pour cent, ce taux fut seulement de 4,2 pour cent chez 118 hommes recevant la triméthoprime-sulfaméthoxazol (4 comprimés d'emblée, suivis par 2 chaque jour pendant 5 jours).

Chez la femme, les résultats de ce dernier traitement furent excellents (2 pour cent de rechutes). Une posologie plus élevée de pénicilline fut employée chez les femmes (1,2 m.u. de benzathine-pénicilline renforcée, suivie le jour suivant de $900.000 \mathrm{u}$. de pénicilline-procaine) et le taux de rechute fut de 7 pour cent.

Aucune réaction toxique significative ne fut notée avec l'un ou l'autre traitement.

On considère brièvement les avantages possibles de l'emploi d'un médicament non tréponémicide. 